\title{
Gambaran Ketergantungan Nikotin pada Rokok Elektronik/Vape Dikalangan Mahasiswa Yogyakarta
}

\author{
Description of the Nicotine Dependence in Electronic Cigarettes/Vape Among \\ Yogyakarta Students
}

\author{
Dima Nurohmah Hayati*, Susi Ari Kristina, Yayi Suryo Prabandari \\ Fakultas Farmasi, Universitas Gadjah Mada \\ Corresponding author: Dima Nurohmah Hayati: Email: dima.n.h@mail.ugm.ac.id \\ Submitted: 05-12-2019 Revised: 26-12-2019 \\ Accepted: 26-12-2019
}

\begin{abstract}
ABSTRAK
Rokok elektronik atau vape adalah salah satu alat yang mengandung nikotin. Peredaran di Indonesia, saat ini merupakan barang yang memiliki dampak negatif bagi masyarakat yakni terdapatnya zat addictive berupa nikotin yang dapat membuat ketergantungan pada penggunanya, termasuk didalamnya adalah pengguna oleh mahasiswa. Tujuan penelitian ini adalah untuk mengetahui ketergantungan nikotin pada rokok elektronik/vape dikalangan mahasiswa Yogyakarta. Teknik sampling yang digunakan adalah convenience sampling menggunakan kuesioner FTND (Fagerstrom Test for Nicotine Dependence) secara online dan hasil disajikan secara deskriptif. Dari total enam pertanyaan FTND, sebanyak 137 responden mahasiswa yang memenuhi kriteria inklusi, diperoleh kriteria dari mayoritas responden adalah berjenis kelamin laki - laki, berusia kurang dari atau sama dengan 22 tahun, sedang menempuh pendidikan Sarjana Strata 1 (S1), dan memiliki pendapatan kurang dari Rp. 1.850.000, dengan mayoritas kategori ketergantungan nikotin adalah low to moderate dan moderate dependence (83.3\% dan 39.4\%). Kesimpulan dari penelitian ini adalah penggunaan rokok elektronik/vape dikalangan mahasiswa dapat menyebabkan ketergantungan nikotin dengan kategori low to moderate.
\end{abstract}

Kata kunci: Vape; Ketergantungan nicotine; Mahasiswa

\section{ABSTRACT}

Electronic cigarette or vape is one of the devices that contain nicotine. In Indonesia, currently it is a device that has a negative impact on society, namely the presence of addictive substances in the form of nicotine that having dependency, including users by students. The purpose of this study was to determine the nicotine dependence on electronic cigarette/vape among Yogyakarta students. The sampling technique used is convenience using the FTND (Fagerstrom Test for Nicotine Dependence) questionnaire via online and the results are presented by descriptively. In total of six FTND questions, 137 student respondents met the inclusion criteria. The majority of respondents obtained were male, aged less than or equal to 22 years old, bachelor degree (S1), and income/pocket money less than IDR 1.850.000, with the majority of nicotine dependence categories were low to moderate and moderate dependence (83.3\% and 39.4\%). The conclusion of this study is the use of e-cigarettes/vape cigarettes among students could affect nicotine dependence with the category of low to moderate.

Keywords: Vape; Nicotine dependence; Students

\section{PENDAHULUAN}

Kandungan kimia dalam rokok adalah nikotin yang berasal dari tembakau, yang mana produk dari tembakau ini terbagi menjadi dua yakni, produk tembakau yang mudah terbakar dan tidak mudah terbakar. Contoh produk tembakau yang mudah terbakar adalah rokok conventional atau tembakau, sedangkan contoh produk tembakau yang tidak mudah terbakar adalah rokok elektronik atau vape (Onor dkk., 2017). Nikotin dalam vape pada uji terkontrol secara acak disebutkan bahwa penggunaan vape lebih efektif dalam mengurangi jumlah merokok konvensional/tembakau (Byrne dkk., 2018), disebutkan pula bahwa penggunaan vape setiap hari dapat memiliki kecenderungan berhenti merokok (Berry dkk., 2018). Akan tetapi terdapat uji coba terkontrol lain yang 
menyebutkan bahwa vape tidak memberikan bukti untuk berhenti merokok konvensional/tembakau (Alawsi dkk., 2015).

Pemerintah di Indonesia melalui peraturan menteri keuangan telah mengatur regulasi berkaitan dengan tarif cukai No. 146 / PMK.010 / 2017, bahwa rokok elektronik yang mengandung nikotin masuk kategori pengolahan tembakau lainnya (Undang-undang, 2007). Ini artinya bahwa rokok elektronik atau vape termasuk barang yang memiliki dampak negatif bagi masyarakat, sehingga peredarannya perlu diawasi, dan penggunaannya perlu mendapat perhatian oleh pemerintah saat ini. Akan tetepi, belum ada peraturan dari menteri kesehatan atau institusi kesehatan lain mengenai rokok elektronik atau vape dalam regulasinya, masih diperlukannya data ilmiah untuk mendukung kebijakan (Badan POM, 2015)

Meningkatnya frekuensi penggunaan rokok elektronik atau vape dapat mempengaruhi ketergantungan nikotin pada vape. Studi sebelumnya mengungkapkan bahwa penggunaan vape dalam waktu lima menit setelah bangun tidur memiliki frekuensi tertinggi dibandingkan frekuensi waktu yang lain (Johnson dkk., 2018). Ketergantungan nikotin ini dapat diukur menggunakan dua metode yakni pengukuran melalui self-reported (pelaporan sendiri oleh perokok) dan pengukuran secara biokimia. Kedua metode ini tidak terdapat perbedaan signifikan untuk mengukur ketergantungan nikotin. Alat yang umumnya digunakan untuk mengukur ketergantungan nikotin secara self-reported yaitu dengan FTND (Fagerstrom Test Nicotine Dependence). Penggunaan alat ini dinilai mampu untuk menilai ketergantungan nikotin pada rokok (Zulkifley dkk., 2017).

Saat ini penggunaan vape terbanyak adalah pada kalangan muda usia produktif $(\mathrm{Ab}$ Rahman dkk., 2019). Sebagian besar merupakan mahasiswa yang memiliki peluang tinggi untuk mencoba vape, mereka beranggapan bahwa vape kurang dapat membuat ketergantungan (Wiseman dkk., 2019). Namun, sebuah studi baru-baru ini menemukan bahwa adanya nikotin dalam rokok elektronik atau vape dapat membuat kecanduan seiring dengan frekuensi penggunaannya dengan metode Electronic Cigarette Dependence Index (ECDI) (Vogel dkk., 2019). Tujuan dari penelitian ini adalah untuk mengetahui ketergantungan nikotin pada rokok elektronik/vape dikalangan mahasiswa Yogyakarta.

\section{METODOLOGI}

Desain dari penelitian ini adalah analisis deskriptif dengan rancangan studi crosssectional. Data dikumpulkan dengan teknik convenience sampling menggunakan kuesioner online kepada mahasiswa yang diundang untuk ikut berpartisipasi melalui direct message instagram. Instrumen yang digunakan adalah kuesioner berupa pertanyaan demografi, riwayat penggunaan dan pertanyaan Fagerstrom Test for Nicotine Dependence (FTND) yang diambil dari Johnson dkk (2018) disesuaikan dengan karakteristik mahasiswa di Yogyakarta. Responden mahasiswa yang menggunakan rokok elektronik atau vape dilihat karakteristiknya terhadap ketergantungan nikotin berdasarkan karakteristik gender, status merokok, rencana untuk berhenti dari rokok tembakau, riwayat penggunaan rokok vape, menandai/memperhatikan vape di internet dan vape store. Pengambilan data pada bulan September hingga Oktober 2019. Kriteria inklusi dalam penelitian ini adalah mahasiswa yang sedang belajar di perguruan tinggi di Yogyakarta berusia lebih dari 17 tahun, menggunakan vape berisi nikotin, dan memiliki ketergantungan nikotin. Kriteria eksklusi dari penelitian ini adalah mahasiswa yang tidak bersedia mengisi kuesioner secara lengkap. Analisis data dilakukan dengan melihat gambaran karakteristik demografi mahasiswa dan riwayat penggunaan, kemudian dilanjutkan dengan menghitung score dari tiap item pertanyaan FTND. Responden kemudian dikelompokan berdasarkan skoring dari FTND, terbagi menjadi empat kelompok yaitu ketergantungan rendah (low dependence) dengan skor 1-2, ketergantungan rendah ke sedang (low to moderate dependence) dengan skor 3-4, ketergantungan sedang (moderate dependence) dengan skor 5-7, dan ketergantungan tinggi (high dependence) dengan skor $8+$.

\section{HASIL DAN PEMBAHASAN}

Sebanyak 1000 responden yang di undang melalui direct message di Instagram terdapat 137 responden mahasiswa yang memenuhi kriteria inklusi. Pada tabel I dapat dilihat karakteristik demografi responden yang 
Tabel I. Demografi Pengguna Vape

\begin{tabular}{|c|c|}
\hline $\begin{array}{c}\text { Karakteristik Responden } \\
\text { Pengguna Vape }\end{array}$ & $\begin{array}{c}\text { Pengguna Vape } \\
\text { n (\%) }\end{array}$ \\
\hline \multicolumn{2}{|l|}{ Jenis Kelamin } \\
\hline Wanita & $5(3,6)$ \\
\hline Pria & $132(96,4)$ \\
\hline \multicolumn{2}{|l|}{ Umur } \\
\hline$\leq 22$ Tahun & $109(79,6)$ \\
\hline >22 Tahun & $28(20,4)$ \\
\hline \multicolumn{2}{|l|}{ Pendidikan } \\
\hline Diploma (D3) & $17(12,4)$ \\
\hline Sarjana Strata 1 (S1) & $115(83,9)$ \\
\hline Pasca Sarjana (S2/S3) & $5(3,6)$ \\
\hline \multicolumn{2}{|l|}{ Pendapatan/Uang saku } \\
\hline$<$ Rp. 1.850 .000 & $84(61,3)$ \\
\hline Rp. $1.850 .000-2.500 .000$ & $37(27,0)$ \\
\hline$>$ Rp. 2.500 .000 & $16(11,7)$ \\
\hline
\end{tabular}

menggunakan vape, mayoritas berjenis kelamin laki - laki, berusia kurang dari atau sama dengan 22 tahun, sedang menempuh pendidikan Sarjana Strata 1 (S1), dan memiliki pendapatan kurang dari Rp. 1.850.000. Penelitian ini sejalan dengan hasil penelitian yang dilakukan oleh Puteh (2018) yang mengungkapkan bahwa usia muda $\leq 21$ tahun, dengan tingkat pendidikan bachelor degree atau setingkat sarjana, serta pendapatan yang lebih rendah merupakan karakteristik demografi dari responden yang pernah mencoba menggunakan rokok elektronik atau vape.

Pendapatan yang lebih rendah dari pengguna vape, apabila mengacu pada peraturan pemerintah Republik Indonesia no. 78 tahun 2015 tentang pengupahan yang hingga kini masih berlaku, upah minimum Yogyakarta adalah sebesar Rp.1.846.400, sehingga dari hasil penelitian ini dapat diketahui bahwa mahasiswa yang menggunakan vape memiliki rata-rata pendapatan/uang saku dibawah upah minimum. Sementara, orang yang memiliki ratarata pendapatan/uang saku diatas pendapatan minimum tidak lebih banyak menggunakan vape.

Nikotin merupakan psikotropika stimultan yang mendatangkan ketenangan, akan tetapi dapat membuat penggunanya menjadi ketergantungan (Subagyo Partodiharjo, 2010). Ketergantungan nikotin dapat berhubungan dengan angka morbiditas dan mortalitas, alat yang digunakan dalam menentukan sejauhmana ketergantungan nikotin adalah dengan FTND yang terdiri dari enam item pertanyaan yang menilai aspek merokok selama periode merokok terberat (Fagerstrom dan Furberg, 2008). Pada tabel II, dapat diketahui persentase ketergantungan nikotin dilihat dari beberapa pertanyaan yang mengacu pada pertanyaan FTND untuk rokok elektronik/vape.

Pada tabel II dapat diketahui persentase ketergantungan nikotin dalam rokok elektronik/vape pada setiap item pertanyaan. Setengah responden mahasiswa yang terlibat dalam penelitian ini menggunakan vape lebih dari satu jam setelah bangun tidur (52.6\%). Sebagian kecil responden lebih suka menggunakan vape di pagi hari $(24.8 \%)$, dan lebih menyukai waktu yang lain selain pagi hari sebagai waktu yang sulit dalam menggunakan vape (85.4\%). Hampir setengah dari responden biasanya menggunakan vape lebih dari 30 kali sehari (53.3\%).

Sebagian besar pengguna vape melaporkan bahwa mereka tidak mengalami kesulitan dalam menahan diri untuk menggunakan vape ditempat terlarang, seperti tempat ibadah, perpustakaan, dll (92.7\%). Serta dilaporkan pula bahwa mereka tidak menggunakan vape meskipun dalam keadaan sakit parah (91.2\%). Penelitian lain yang dilakukan oleh Johnson dkk (2018) mengkapkan bahwa pengguna vape tidak mengalami cemas dan gelisah karena tidak bisa menggunakan vape, serta banyak dari pengguna 
Tabel II. Persentase Ketergantungan Nikotin Pada Setiap Item Pertanyaan

\begin{tabular}{lcc}
\hline \multicolumn{1}{c}{ Karakteristik } & \% & (n) \\
\hline Setelah anda bangun tidur, berapa lama waktu yang dibutuhkan untuk menggunakan vape? \\
Dalam waktu 5 menit setelah bangun tidur & 7,3 & 10 \\
6 - 30 menit setelah bangun tidur & 22,6 & 31 \\
31 - 60 menit setelah bangun tidur & 17,5 & 24 \\
Lebih dari 1 jam setelah bangun tidur & 52,6 & 72 \\
Apakah anda mengalami kesulitan dalam menahan keinginan untuk merokok di tempat \\
yang dilarang untuk merokok? Contoh: tempat ibadah, perpustakaan, dll. & 10 \\
Ya & 7,3 & 127 \\
Tidak & 92,7 & 20 \\
Kapan waktu yang sulit bagi anda untuk tidak menggunakan vape? & 14,6 & 117 \\
Rokok pertama di pagi hari & 85,4 & 10 \\
Di waktu yang lain & & 36 \\
Berapa kali sehari biasanya anda menggunakan vape? & 7,3 & 18 \\
0 - 9 kali & 26,3 & 73 \\
10 - 19 kali & 13,1 & \\
20 - 29 kali & 53,3 & 34 \\
Lebih dari 30 kali & & 103 \\
Apakah anda lebih sering menggunakan vape di pagi hari? & 24,8 & 12 \\
Ya & 75,2 & 125 \\
Apakah anda tetap merokok meskipun dalam keadaan sedang sakit parah? & 8,8 & 91,2 \\
Ya & & \\
Tidak & & \\
\hline
\end{tabular}

vape mengatakan bahwa tidak atau sedikitnya pernah memiliki keinginan yang kuat untuk menggunakan vape diwaktu tertentu.

Tabel III menggambarkan karakteristik pengguna rokok elektronik/vape dengan empat kategori ketergantungan nikotin pada vape terhadap responden mahasiswa yang menyelesaikan semua pertanyaan FTND $(n=137)$. Dari hasil penelitian ini diketahui bahwa riwayat penggunaan vape memiliki hubungan yang signifikan dengan ketergantungan nikotin dengan kategori ketergantungan nikotin low to moderate atau rendah ke sedang menggunakan vape setiap hari $(83.3 \%)$. Hal ini berbanding terbalik dengan penelitian sebelumnya yang mengungkapkan bahwa terdapat sedikitnya orang yang ketergantungan nikotin. Kebanyakan orang yang menggunakan vape memiliki ketergantungan moderate dan high dependence (Etter dan Eissenberg, 2015; Johnson dkk., 2018). Akan tetapi, kategori ketergantuan nicotine tersebut tidak spesifik menyebutkan terhadap mahasiswa. Penelitian terbaru mengungkapkan bahwa mahasiswa yang menggunakan vape dikategorikan low to moderate, karena menggunakan konsentrasi nikotin yang rendah (Jankowski dkk., 2019).

Persentase responden mahasiswa memiliki status merokok yang hanya menggunakan vape dikategorikan sebagai ketergantungan nikotin low to moderate atau rendah ke sedang (80.3\%). Banyak dari mereka dalam kategori ini memperhatikan iklan vape di internet dan vape store dalam 30 hari $(72.7 \%$ dan $78.8 \%$ ). Frekuensi mengunjungi situs web atau blog vape di internet memiliki hubungan yang signifikan dengan ketergantungan nikotin, karena setidaknya satu kali seminggu website tersebut dikunjungi (Johnson dkk., 2018).

Sebanyak (39.4\%) responden mahasiswa menggunakan secara ganda rokok vape dan rokok tembakau dikategorikan sebagai moderate dependence atau ketergantungan nikotin yang sedang. Akan tetapi, sebagian besar mereka tertarik untuk berhenti merokok tembakau dalam kurun waktu satu tahun atau lebih. Hal ini berbeda dengan penelitian sebelumnya yang mengungkapkan bahwa pengguna ganda memiliki ketergantungan yang lemah pada rokok vape daripada rokok tembakau, dan penggunaan ganda tidak 
Tabel III. Karakteritik Ketergantungan Nicotine

\begin{tabular}{|c|c|c|c|c|c|}
\hline Karakteristik & $\begin{array}{c}\text { Low Dep. } \\
\text { N (\%) }\end{array}$ & $\begin{array}{c}\text { Low to } \\
\text { Moderate } \\
\text { Dep. N (\%) }\end{array}$ & $\begin{array}{c}\text { Moderate } \\
\text { Dep. } \\
\text { N (\%) } \\
\end{array}$ & $\begin{array}{c}\text { High Dep. } \\
\text { N (\%) }\end{array}$ & $p$-value \\
\hline \multicolumn{6}{|l|}{ Gender } \\
\hline Male & $33(91,6)$ & $66(100)$ & $31(93,9)$ & $2(100)$ & \multirow{2}{*}{0,147} \\
\hline Female & $2(8,4)$ & $0(0)$ & $2(6,1)$ & $0(0)$ & \\
\hline \multicolumn{6}{|l|}{ Status merokok } \\
\hline Pengguna Vape & $24(66,7)$ & $53(80,3)$ & $20(60,6)$ & $1(50)$ & \multirow{2}{*}{0,151} \\
\hline Vape+Rokok Tembakau & $12(33,3)$ & $13(19,7)$ & $13(39,4)$ & $1(50)$ & \\
\hline \multicolumn{6}{|c|}{ Rencana berhenti rokok tembakau } \\
\hline Tertarik berhenti & $9(75,0)$ & $12(92,3)$ & $13(100)$ & $1(100)$ & \multirow{2}{*}{0,210} \\
\hline Tidak tertarik berhenti & $3(25,0)$ & $1(7,7)$ & $0(0)$ & $0(0)$ & \\
\hline \multicolumn{6}{|c|}{ Riwayat penggunaan vape } \\
\hline Setiap hari & $22(61,1)$ & $55(83,3)$ & $31(93,9)$ & $2(100)$ & \multirow{2}{*}{$0,004^{*}$} \\
\hline Kadang - kadang & $14(38,9)$ & $11(16,7)$ & $2(6,1)$ & $0(0)$ & \\
\hline \multicolumn{6}{|c|}{ Memperhatikan vape di internet dalam 30 hari } \\
\hline Ya & $21(58,3)$ & $48(72,7)$ & $25(75,7)$ & $2(100)$ & \multirow{2}{*}{0,267} \\
\hline Tidak & $15(41,7)$ & $18(27,3)$ & $8(24,3)$ & $0(0)$ & \\
\hline \multicolumn{6}{|c|}{ Memperhatikan vape di vapestore dalam 30 hari } \\
\hline Ya & $26(72,2)$ & $52(78,8)$ & $27(81,8)$ & $2(100)$ & \multirow{2}{*}{0,666} \\
\hline Tidak & $10(27,8)$ & $14(21,2)$ & $6(18,2)$ & $0(0)$ & \\
\hline
\end{tabular}

Keterangan: Dep. $=$ Dependence; ${ }^{*} P$-value $<0.05$ ada hubungan yang signifikan

memiliki dampak sebagai upaya berhenti merokok tembakau, terlebih alasan mereka menggunakannya karena menikmati vape (Etter dan Eissenberg, 2015).

Kami menyadari bahwa dalam penelitian ini masih memiliki keterbatasan dalam penyusunan. Dalam penelitian ini kami tidak mengakses berapa jumlah nikotin yang digunakan oleh penggunanya, serta penggunaan vape untuk subtitusi rokok tembakau. Dibutuhkan pertanyaan-pertanyaan yang lebih mendalam terkait dengan ketergantungan nikotin pada rokok elektronik serta serta penggunaan vape untuk subtitusi rokok tembakau, karena kami menemukan hubungan signifikan antara riwayat penggunaan vape dengan ketergantungan nikotin.

\section{KESIMPULAN}

Dalam penelitian ini menunjukkan bahwa karakteristik demografi didominasi oleh laki-laki, mahasiswa yang sedang menempuh pendidikan sarajana (S1) dan dengan pendapatan uang saku dibawah upah minimum. Penggunaan rokok vape dikalangan mahasiswa dapat menyebabkan ketergantungan nikotin dengan kategori low to moderate.

\section{UCAPAN TERIMA KASIH}

Disampaikan ucapan terimakasih kepada Dr. Susi Ari Kristina, M.Kes., Apt dan Prof. Dra. RA. Yayi Suryo Prabandari, M.Si.,PhD selaku dosen pembimbing yang telah memberikan saran dan kritik terkait dengan penelitian kami dan juga kepada Fakultas Farmasi Universitas Gadjah Mada untuk fasilitas yang disediakan dalam penelitian ini.

\section{DAFTAR PUSTAKA}

Ab Rahman, J., Mohd Yusoff, M.F., Nik Mohamed, M.H., Mahadir Naidu, B., Hock, L.K., Hiong, T.G., dkk., 2019. The Prevalence of ECigarette Use Among Adults in Malaysia: Findings From the 2016 National ECigarette Survey. Asia Pacific Journal of Public Health, 00: 1-13.

Alawsi, F., Nour, R., dan Prabhu, S., 2015. Are ecigarettes a gateway to smoking or a pathway to quitting? British Dental Journal, 219: 111.

Badan POM, 2015. Info POM: Bahaya Rokok Elektronik Racun Berbalut Teknologi. Badan POM RI, Jakarta.

Berry, K.M., Reynolds, L.M., Collins, J.M., Siegel, M.B., Fetterman, J.L., Hamburg, N.M., dkk., 
2018. E-cigarette initiation and associated changes in smoking cessation and reduction: the Population Assessment of Tobacco and Health Study, 2013-2015. Tobacco Control, 28: 42-49.

Byrne, S., Brindal, E., Williams, G., Anastasiou, K., Tonkin, A., Battams, S., dkk., 2018. ECigarettes, Smoking and Health: A Literature Review Update. CSIRO, Australia.

Etter, J.-F. dan Eissenberg, T., 2015. Dependence levels in users of electronic cigarettes, nicotine gums and tobacco cigarettes. Drug and Alcohol Dependence, 147: 6875.

Fagerström, K. dan Furberg, H., 2008. A comparison of the Fagerström Test for Nicotine Dependence and smoking prevalence across countries. Addiction, 103: 841-845.

Jankowski, Krzystanek, Zejda, Majek, Lubanski, Lawson, dkk., 2019. E-Cigarettes are More Addictive than Traditional Cigarettes-A Study in Highly Educated Young People. International Journal of Environmental Research and Public Health, 16: 2279.

Johnson, J.M., Muilenburg, J.L., Rathbun, S.L., Yu, X., Naeher, L.P., dan Wang, J., 2018. Elevated Nicotine Dependence Scores among Electronic Cigarette Users at an Electronic Cigarette Convention. Journal of community health, 43: pp.164174.

Onor, I.O., Stirling, D.L., Williams, S.R., Bediako, D., Borghol, A., Harris, M.B., dkk., 2017.
Clinical Effects of Cigarette Smoking: Epidemiologic Impact and Review of Pharmacotherapy Options. International Journal of Environmental Research and Public Health, 14: 1147.

Subagyo Partodiharjo, 2010. Kenali Narkoba Dan Musuhi Penyalahgunaannya. Esensi, Jakarta.

Undang-undang, 2007. Undang-Undang Republik Indonesia No. 39 tahun 2007 tentang Perubahan Atas Undang-Undang No. 11 tahun 1995 tentang Cukai.

Vogel, E.A., Prochaska, J.J., dan Rubinstein, M.L., 2019. Measuring e-cigarette addiction among adolescents. Tobacco Control, tobaccocontrol-2018.

Wan Puteh, S.E., Abdul Manap, R., Maharani, H., Ahmad, I.S., Idris, I.B., Md Sham, F., dkk., 2018. The use of e-cigarettes among university students in Malaysia. Tobacco Induced Diseases, 16: .

Wiseman, K.P., Margolis, K.A., Bernat, J.K., dan Grana, R.A., 2019. The association between perceived e-cigarette and nicotine addictiveness, informationseeking, and e-cigarette trial among U.S. adults. Preventive Medicine, 118: 66-72.

Zulkifley, N.H., Ismail, S., Manaf, R.A., dan Hamid, Z., 2017. The Correlation of Two Nicotine Dependence Measurement Methods: Fagerstrom Test for Nicotine Dependence (FTND) and Saliva Cotinine among a Group of Muslim Smoker in Malaysia. Malaysian Journal of Medicine and Health Sciences, 13: 43-50.. 